\title{
Control of Bacterial Blight Disease of Pomegranate Using Silver Nanoparticles
}

\author{
Sherkhane AS ${ }^{1 *}$, Suryawanshi $\mathrm{HH}^{1}$, Mundada $\mathrm{PS}^{2}$ and Shinde BP ${ }^{2}$
}

${ }^{1}$ Department of Biotechnology, Vidya Pratishthan's Arts, Science and Commerce College, Baramati, India

${ }^{2}$ Department of Biotechnology, Yashavantrao Chavan Institute of Science, Satara, India

\begin{abstract}
Successful cultivation is difficult to pomegranate growers due to Xanthomonas axonopodis pv. punicae which cause bacterial blight disease to pomegranate has become serious threat. However, everyone is looking for solution; this problem is resolved by synthesizing silver nanoparticles by the reduction of silver ions in aqueous solutions with the help of green synthesis method. In the present study the causative agent was isolated from the infected pomegranate fruits and was tested with silver nanoparticles which are synthesized from leaf extracts of Tulsi, Neem, Tridax and Drumstick at variable concentrations and it was found that silver nanoparticle containing Tulsi extract with $15 \mathrm{mM}$ concentration showed maximum zone of inhibition $(22 \mathrm{~mm})$, then Tridax $(20 \mathrm{~mm})$, Neem $(19 \mathrm{~mm})$ and Drumstick $(18$ $\mathrm{mm}$ ) while at $1 \mathrm{mM}$ concentration it shows minimum. The bioreduction was tested by using UV-Vis Spectrophotometer. This study showed that by using synthesized silver nanoparticles we successfully controlled the growth of Xanthomonas axonopodis pv. Punicae. They can be used in the field of medical as well as in the management of plant diseases.
\end{abstract}

Keywords: Bacterial blight; Xanthomonas axonopodis; Silver nitrate; Nanoparticles; Antimicrobial activity

\section{Introduction}

Pomegranate is important fruit crops which are cultivated in arid and semiarid regions of the world; however is gaining lot of attention of total world over due to its high nutritional and economics values $[1,2]$. In addition pomegranate is used in several purposes as diarrhea, ulcers [3], diabetes [4], male infertility [5], and antiparasitic agent [6]. In the recent year pomegranate cultivation is creating problem due to bacterial blight disease Xanthomonas axonopodis Pv. Punicae which shows on leaves, stems as well as on fruits and reduce crop yield up to $60-80 \%$. This disease could not be effectively controlled by antibiotics, chemicals [7-9]. Now a day, Nanoscience is rapidly growing field with great application for generating nanoparticles and biosynthesis of silver nanoparticles by using medicinal plants in agriculture due to their diverse effect [10]. Silver nanoparticles have great importance in the field of medical due to its broad spectrum application in the medical field $[11,12]$. The synthesis of nanoparticles by biological method show better results than the chemical methods and is easily scaled up for large scale synthesis and cost effective $[13,14]$. The use of plant extract for the synthesis of nanoparticles is adventitious, because it does not require the processes like intracellular synthesis, purification steps and the maintenance of microbial cell cultures. In the present study the causative agent was isolated from the infected pomegranate fruits and to control of this disease silver nanoparticles were synthesized from leaf extracts of Tulsi, Neem, Tridax, and Drumstick at variable concentrations ( $1 \mathrm{mM}, 5 \mathrm{mM}, 10 \mathrm{mM}$ and $15 \mathrm{mM}$ ). However, the plant extracts are potentially effective than microorganisms with respect to stabilization by provide capping agents for the silver nanoparticles, prevent the aggregation of nanoparticles and free from toxic chemicals [15]. Antimicrobial activity of silver nanoparticles depends mostly on the relative surface area; even though; the smaller silver nanoparticles can have greater toxic potentials [16-18]. However, the results were confirmed and characterized by UV-Visible spectroscopy and Antimicrobial activity of silver nanoparticles was evaluated against bacterial blight disease Xanthomonas axonopodis Pv. Punicae for diagnosis, treatment, control and to manage disease which will be beneficial to farmers as well as further studies must be conducted to verify if the bacteria develop resistance towards the nanoparticles or not.

\section{Materials and Methods}

\section{Sample collection of infected fruits}

The infected fruits showing the typical symptoms of bacterial spot were collected from farmer's fields of major pomegranate growing areas of Baramati in Pune district. The fruits showing typical symptoms like yellowish brown spots, decolouration, minute water soaked lesions, cankers lesions and irregular yellow and brown patches.

\section{Isolation of disease causing bacteria from infected fruit part}

Infected Fruits samples are collected from orchard. Ooze test is performed by cutting $1 \mathrm{~cm}$ of the infected portion of the fruit and the outer surface was removed and sterilized with $0.1 \% \mathrm{HgCl}_{2}$ solution for 1 minute and are 3 times washed with sterile distilled water. Then the infected portion was squeezed gently with a sterile scalpel to get a suspension in a sterile test tube containing $3 \mathrm{ml}$ of sterilized saline. The suspension was serially diluted and plated in sterilized petriplates containing YDC Agar medium (Yeast extract-10 g/L, Dextrose-20 g/L, Calcium carbonate- $20 \mathrm{~g} / \mathrm{L}$, Agar- $25 \mathrm{~g} / \mathrm{L}, \mathrm{pH}$ 6.5).Inoculated plates were incubated at $30^{\circ} \mathrm{C}$ for 72 hours. After the incubation period, light yellow colored bacterial colonies were developed resembling Xanthomonas sp. further Cultures were screened based on biochemical characterization according to Bergey's manual of Determinative Bacteriology (Figure 1).

\section{Purification of bacterial culture}

The suspected bacterial colonies were picked up with the help of sterilized inoculated loop and streaked onto the surface of YDC Agar. The inoculated plates were incubated at $30^{\circ} \mathrm{C}$ for 72 hours and the

*Corresponding author: Sherkhane AS, Dept. of Biotechnology, Vidya Pratishthan's Arts, Science and Commerce College, Baramati, India, Tel: 2112239386; E-mail: assherkhane@gmail.com

Received: May 15, 2018; Accepted: May 22, 2018; Published: May 28, 2018

Citation: Sherkhane AS, Suryawanshi HH, Mundada PS, Shinde BP (2018) Control of Bacterial Blight Disease of Pomegranate Using Silver Nanoparticles. J Nanomed Nanotechnol 9: 500. doi: 10.4172/2157-7439.1000500

Copyright: (C) 2018 Sherkhane AS, et al. This is an open-access article distributed under the terms of the Creative Commons Attribution License, which permits unrestricted use, distribution, and reproduction in any medium, provided the original author and source are credited. 
Citation: Sherkhane AS, Suryawanshi HH, Mundada PS, Shinde BP (2018) Control of Bacterial Blight Disease of Pomegranate Using Silver Nanoparticles. J Nanomed Nanotechnol 9: 500. doi: 10.4172/2157-7439.1000500

Page 2 of 5

observations were made for the development of well separated light yellow colored bacterial colonies. The purified bacterial colonies were streaked on nutrient agar slants and stored at $4^{\circ} \mathrm{C}$ in refrigerator and also in sterile distilled water taken in small culture tubes, by suspending 2-3 loops full of the bacterial culture for future use.

\section{Identification of causal organism}

The morphological characteristics such as cell shape, gram staining (Table 1) and Biochemical test (Table 2) was performed for the identification of causative agent of oil spot disease of the isolate.

\section{Synthesis of silver nanoparticals by using plant extracts}

Around $5 \mathrm{~g}$ of fresh tulsi, tridax, drumstick and neem leaves were collected from the Bio-village, VSBT of VPASC College, Baramati. All the veins were removed and leaves were crushed in deionized water. After crushing the extract was filtered using whatman's filter paper no.1. The $2 \mathrm{ml}$ and $5 \mathrm{ml}$ of extract filtrate was collected and then added in various concentrations of silver nitrate solution $(1 \mathrm{mM}, 5 \mathrm{mM}$ and $10 \mathrm{mM}, 15 \mathrm{mM}$ ). This reaction was kept under dark condition for more than a week. Tubes were monitored after every 24 hours and reactions showing precipitation of silver particles were discarded. After 15 days reaction the color of the solution of silver nanoparticles was analyzed by UV visible spectroscopy (Figure 2). Reaction showing peaks at around 390-430 nm was chosen for further study (Table 3). This solution was centrifuged at 10,000 rpm for 10 minutes, and the precipitate of silver nanoparticles was washed in methanol three times. The resulting pellet was dried in oven at $65^{\circ} \mathrm{C}$ for $24 \mathrm{~h}$ and then collected in tubes for further use.

\section{Antimicrobial analysis}

Biosynthesized Silver nanoparticles were tested for antimicrobial activity against isolated oil spot disease causing bacteria. Freshly prepared $100 \mu \mathrm{l}$ of the isolated pathogen was spread on the sterile nutrient agar plates. By using cork borer a hole was made in the petriplates. Then $100 \mu \mathrm{l}$ of each suspension of milli-Q water as a control, silver nanoparticles, silver nitrate as positive control was added into the wells. Plates were incubated at $37^{\circ} \mathrm{C}$ for 24 hours, and then the zone of inhibition was measured in mm (Figures 3, 4 and Table 4).

\section{Result and Discussion}

The yellow and pale yellow coloured colonies were observed on the YDC Agar medium. The morphological characters of the isolate were

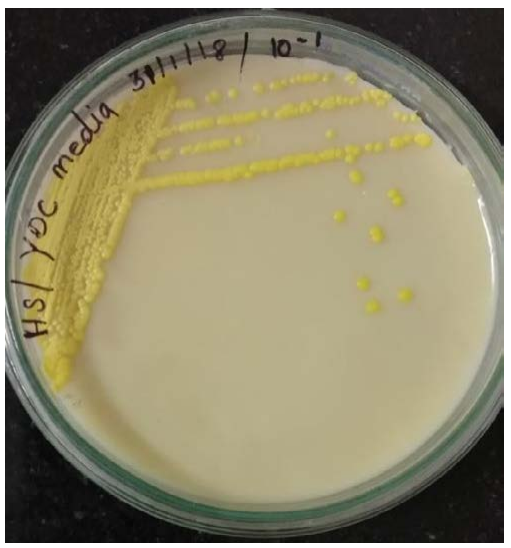

Xanthomonas spp.-I

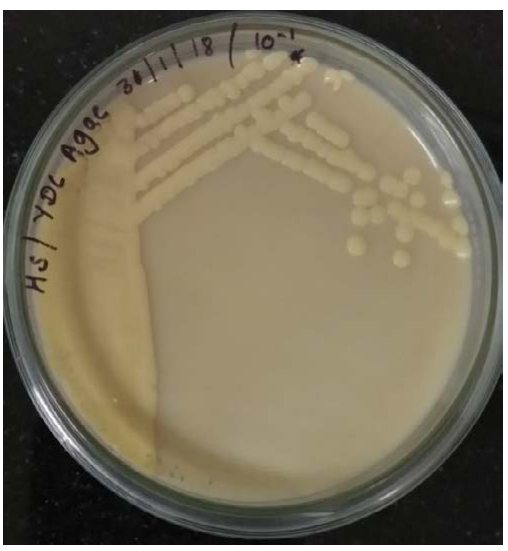

Xanthomonas spp.-II

Figure 1: The Results of isolates on YDC Agar plates.

\begin{tabular}{|l|c|c|c|c|c|c|c|}
\hline Isolate & Size & Shape & Colour & margin & elevation & consistency & Opacity \\
\hline Xanthomonas spp.-I & $2 \mathrm{~mm}$ & Circular & Yellow & Regular & Elevated & sticky & Opaque \\
\hline Xanthomonas spp.-II & $3 \mathrm{~mm}$ & Circular & Pale yellow & Regular & Elevated & Moist & Opaque \\
\hline
\end{tabular}

Table 1: Colony characters of isolated pathogens.

\begin{tabular}{|c|c|c|c|}
\hline Sr. No & Characteristics & Xanthomonas spp.-I & - \\
\hline 1 & Methyl Red Test & - & - \\
\hline 2 & Voges Proskauer Test & - & - \\
\hline 3 & Indole Test & + \\
\hline 4 & Catalase Test & - \\
\hline
\end{tabular}

Table 2: Biochemical tests for identification of isolates.

\begin{tabular}{|c|c|c|}
\hline Common name of plants used for synthesis of AgNP's & Scientific name \\
\hline Neem & Aulsi & Azadirachta indica \\
\hline Drumstick & Ocimum tenuiflorum \\
\hline Tridax & Moringa oleifera \\
\hline
\end{tabular}

Table 3: Common Name of Plants used for synthesis of AgNP's, Scientific Name and their Spectral analysis of extracts was carried to find out $\lambda$-max of nanoparticles. $\lambda$-max for nanoparticles isolated from different plants listed below. 
Citation: Sherkhane AS, Suryawanshi HH, Mundada PS, Shinde BP (2018) Control of Bacterial Blight Disease of Pomegranate Using Silver Nanoparticles. J Nanomed Nanotechnol 9: 500. doi: 10.4172/2157-7439.1000500

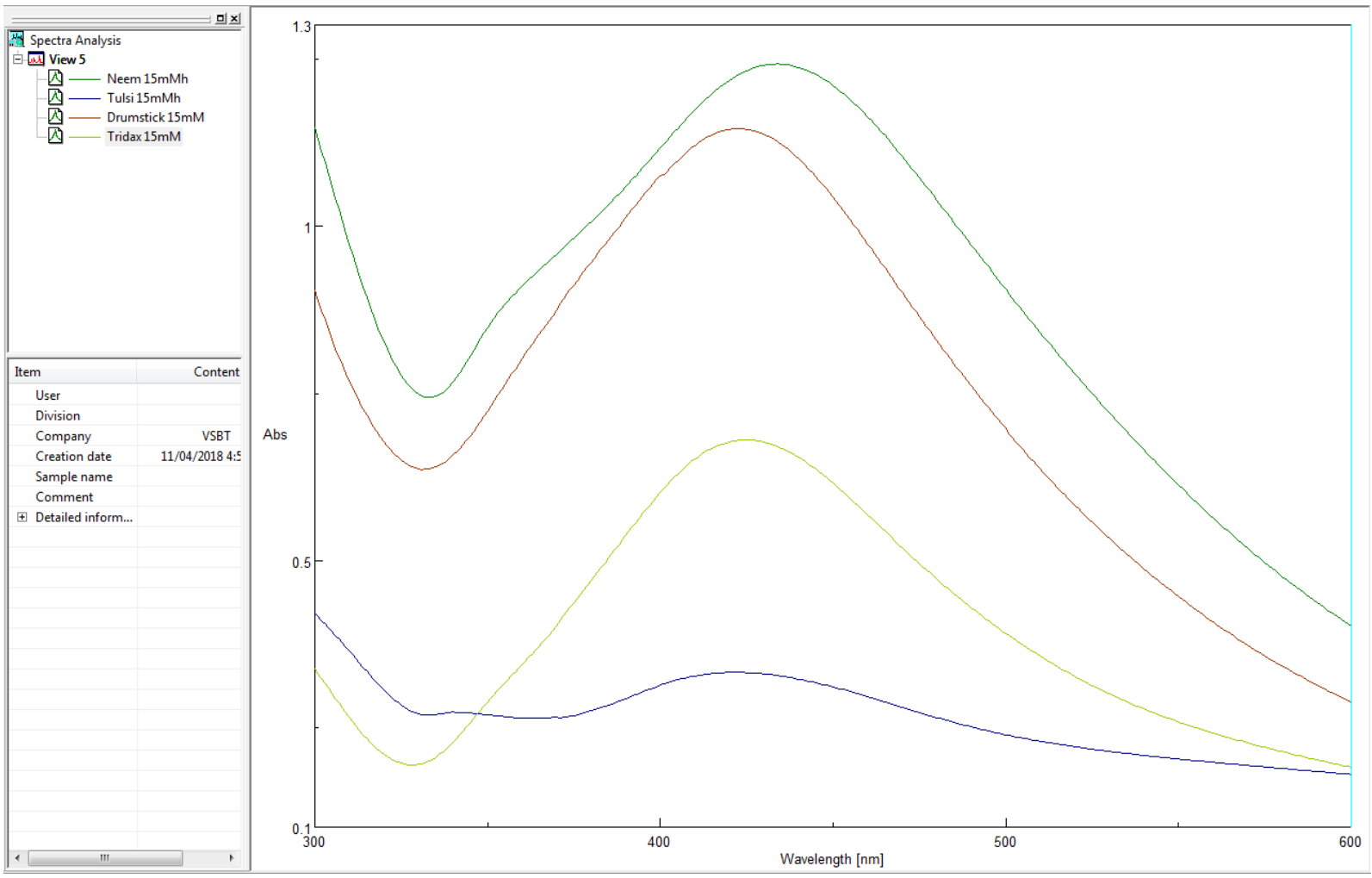

Figure 2: Spectral analysis of silver nanoparticle at $15 \mathrm{mM}$ concentration.

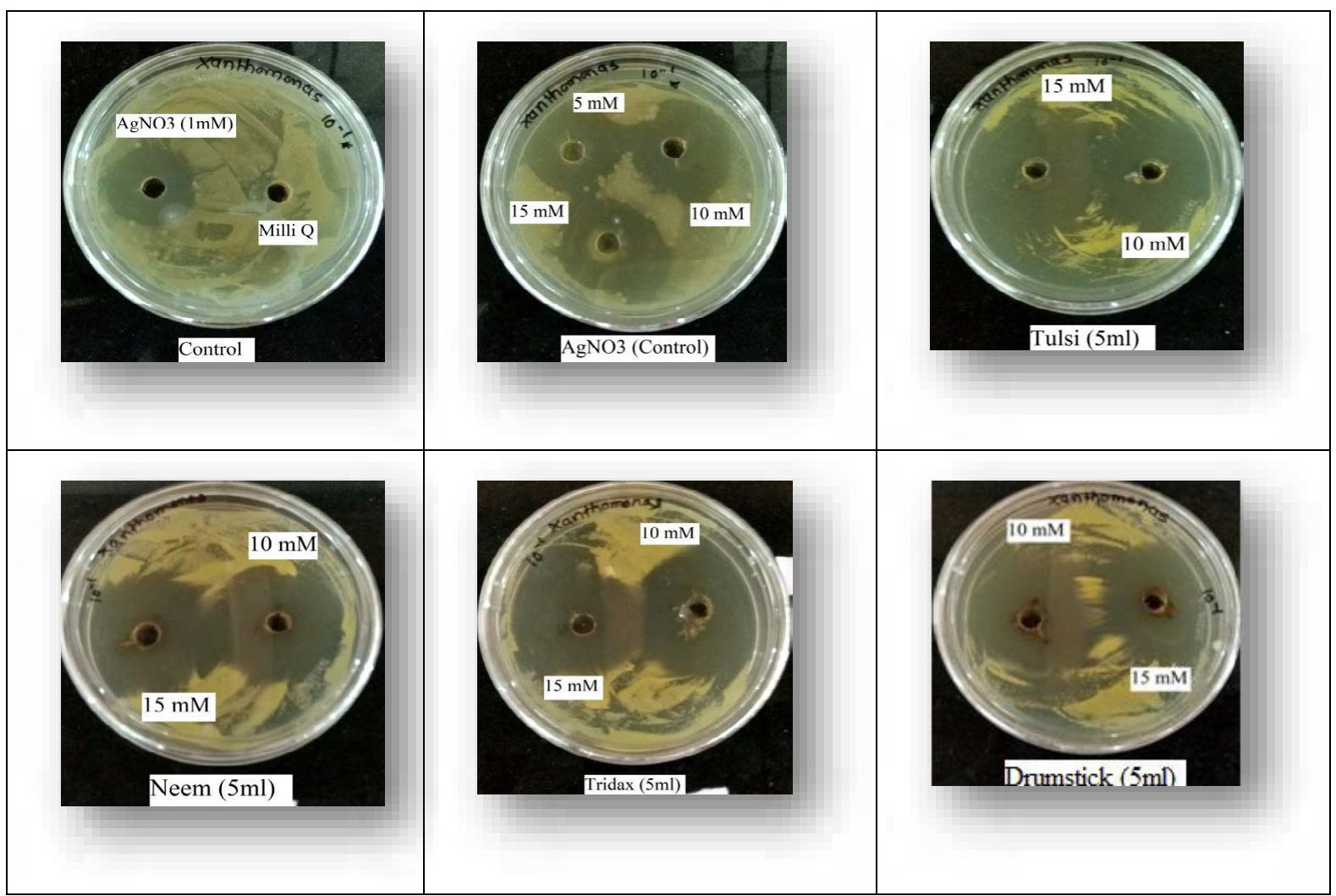

Figure 3: Result showing the antibacterial activity of control, $\mathrm{AgNO}_{3}$ (control), tulsi, tridax, drumstick and neem at (10 mM conc.) against $\mathrm{Xanthomonas} \mathrm{axonopodis}$ pv. punicae. 
Citation: Sherkhane AS, Suryawanshi HH, Mundada PS, Shinde BP (2018) Control of Bacterial Blight Disease of Pomegranate Using Silver Nanoparticles. J Nanomed Nanotechnol 9: 500. doi: 10.4172/2157-7439.1000500

studied (Table 1). This isolate was characterized by the biochemical tests and the causative agent was may belongs to Xanthomonas spp.

\section{Biochemical characteristics of isolates}

The biochemical characters of isolate Xanthomonas spp.-I, Xanthomonas spp.-II (Scheme 1). Identification of isolates was done by comparing various colony morphological and biochemical tests according to Bergy's manual.

\section{Synthesis of silver nanoparticle}

As the leaf extracts were added to different concentrations of aqueous silver nitrate solution, the colour of the solution changed from faint light to yellowish brown to reddish brown and finally to colloidal brown indicating AgNP formation. The completion of reaction between leaf extract and $\mathrm{AgNO}_{3}$ was observed. Absorption spectra of AgNPs formed in the reaction media has absorption maxima in the range of 420 to $460 \mathrm{~nm}$.

\section{UV visible spectral analysis}

UV visible spectral analysis has given in Figure 2.

\section{Anti-microbial activity of extract}

The antimicrobial activity shows most rapid bioreduction in $5 \mathrm{ml}$ extract of Tulsi, Neem, Drumstrick and Tridax of $15 \mathrm{mM}$ concentration

\begin{tabular}{|l|c|c|c|}
\hline Organism & \multicolumn{2}{|c|}{ Xanthomonas spp.-I } & \multicolumn{2}{|c|}{ Xanthomonas spp.-II } \\
\hline Positive Control $\left(\mathrm{AgNO}_{3}\right)$ & \multicolumn{2}{|c|}{$12 \mathrm{~mm}$} & AgNP's \\
\hline Sample & Leaf extract & $18 \mathrm{~mm}$ & Leaf extract \\
\hline Drumstick & $6 \mathrm{~mm}$ & $19 \mathrm{~mm}$ & $7 \mathrm{~mm}$ \\
\hline Neem & $5 \mathrm{~mm}$ & $5 \mathrm{~mm}$ & $15 \mathrm{~mm}$ \\
\hline Tridax & $8 \mathrm{~mm}$ & $20 \mathrm{~mm}$ & $7 \mathrm{~mm}$ \\
\hline Tulsi & $8 \mathrm{~mm}$ & $22 \mathrm{~mm}$ & $19 \mathrm{~mm}$ \\
\hline
\end{tabular}

The results are average of three replicates.

Table 4: Antibacterial activity of plant extract which were treated with $\mathrm{AgNO}_{3}$ and $\mathrm{AgNPs}$ against Xanthomonas axonopodis pv. punicae showing zone of inhibition (mm).

\section{Antimicrobialactivity of AgNP's Against Xanthomonas spp.- I}

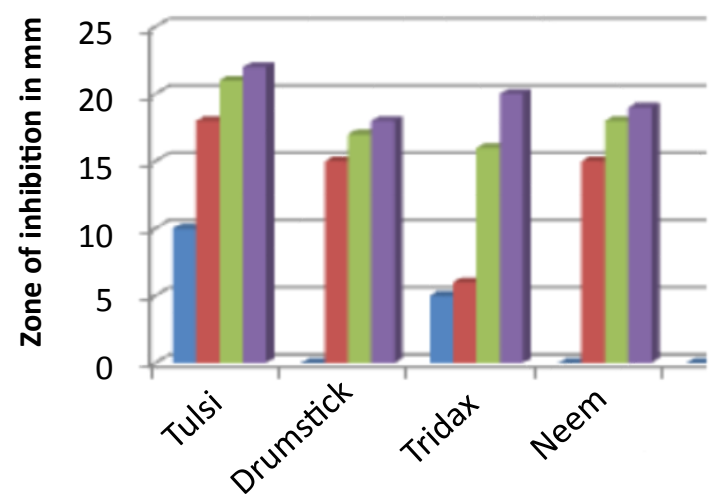

$$
\begin{aligned}
& =1 \mathrm{mM} \\
& =5 \mathrm{mM} \\
& =10 \mathrm{mM} \\
& =15 \mathrm{mM}
\end{aligned}
$$

Figure 4: Antimicrobial activity of AgNP's, prepared by adding $5 \mathrm{ml}$ plant extract against Xanthomonas spp.-I. In this graph it was found that silver nanoparticle from Tulsi extract with $15 \mathrm{mM}$ concentration (nanoparticle synthesised by adding $5 \mathrm{ml}$ of plant extract) showed maximum zone of inhibition ( $22 \mathrm{~mm}$ ), then Tridax ( $20 \mathrm{~mm}$ ), Neem $(19 \mathrm{~mm})$ and Drumstick $(18 \mathrm{~mm})$ while at $1 \mathrm{mM}$ concentration it shows minimum.

\begin{tabular}{|c|c|c|}
\hline Isolate & Gram nature & Motility \\
\hline Xanthomonas I & Gram Negative Cooci & \\
\hline & & \\
\hline
\end{tabular}

Scheme 1: Colony characteristics. 
Citation: Sherkhane AS, Suryawanshi HH, Mundada PS, Shinde BP (2018) Control of Bacterial Blight Disease of Pomegranate Using Silver Nanoparticles. J Nanomed Nanotechnol 9: 500. doi: 10.4172/2157-7439.1000500

of silver nitrate solution. Results obtained are shown in Table 2. The inhibition zones obtained indicates maximum antibacterial activity of the prepared test sample.

\section{Conclusion}

Xanthomonas axonopodis pv. punicae which cause bacterial blight disease to the Pomegranate that affects around $80 \%$ of the production. The current scenario, Nanotechnology provides a good platform to overcome the problem and resolved it with help of synthesizing silver nanoparticles from leaf extracts of Tulsi, Neem, Tridax and Drumstick at variable concentrations. And the causative agent from the infected fruits was treated with silver nanoparticles at variable concentrations. In this study it was observed that silver nanoparticles with the concentration $15 \mathrm{mM}$ showed highest antimicrobial activity and minimum at $5 \mathrm{mM}$. This study showed that synthesized silver nanoparticles having bactericidal potential and successfully controlled the growth of Xanthomonas axonopodis pv. punicae. Therefore, silver nanoparticles would be used as powerful weapons against Xanthomonas axonopodis pv. punicae even at very lower concentrations.

\section{References}

1. Mondal KK, Sharma J (2009) Bacterial blight: an emerging threat to pomegranate export. Indian Farming 59: 22-23.

2. Jurenka JS (2008) Therapeutic applications of pomegranate (Punica granatum L.): A Review. Altern Med Rev 13: 128-144.

3. Caceres A, Giron LM, Alvarado SR, Torres MF (1987) Screening of antimicrobia activity of plants popularly used in Guatemala for treatment of dermatomucosal diseases. J Ethnopharmacol 20: 223-237.

4. Saxena A, Vikram NK (2004) Role of selected Indian plants in management of type 2 diabetes: a review. J Altern Complement Med 10: 369-378.

5. Turk G, Sonmez M, Aydin M, Yuce A, Gur S, et al. (2008) Effects of pomegranate juice consumption on sperm quality, spermatogenic cell density, antioxidant activity, and testosterone level in male rats. Clin Nutr 27: 289-296.

6. Naqvi SAH, Khan MSY, Vohora SB (1991) Antibacterial, antifungal, and antihelminthic investigations on Indian medicinal plants. Fitoterapia 62: 221-228.
7. Dassprakash MV, Arun R, Abraham SK, Premkumar K (2012) In vitro and in vivo evaluation of antioxidant and antigenotoxic potential of Punica granatum leaf extract. Pharm Biol 50: 1523-1530.

8. Ambadkar CV, Dhawan AS, Shinde VN (2015) Integrated management of bacterial blight disease (oily spot) of pomegranate caused by Xanthomonas axonopodis pv.punicae. Internat J Plant Sci 10: 19-23.

9. Lokesh R, Erayya, Kumaranag KM, Chandrashekar N, Khan ANA (2014) In vivo efficacy of some antibiotics against Bacterial Blight of Pomegranate caused by Xanthomonas axonopodis pv. punicae. International Research Journal of Biological Sciences 3: 31-35.

10. Kumar R, Jahagirdar MRS, Yenjerappa ST, Patil HB (2009) Epidemiology and management of bacterial blight of Pomegranate caused by Xanthomonas axonopodis pv. Punicae. Acta Hort. Acta Hortic 818: 291-296.

11. Du J, Yi T (2016) Biosynthesis of silver nanoparticles by Variovorax guangxiensis THG-SQL3 and their antimicrobial potential. Mater Lett 178: 75-78.

12. Xu ZP, Zeng Q, Lu M, Yu A (2006) Inorganic nanoparticles as carriers for efficient cellular delivery. Chem Eng Sci 61: 1027-1040.

13. Banerjee P, Satapathy MK, Mukhopahayay A, Das P (2014) Leaf extract mediated green synthesis of silver nanoparticles from widely available Indian plants: Synthesis, characterization, antimicrobial property and toxicity analysis. Biores Bioproc.

14. Forough M, Farhadi K (2010) Biological and green synthesis of silver nanoparticles. Turk J Eng Enviorn Sci 34: 281-287.

15. Logeswari, P, Sivagnanam S, Abraham J (2013) Ecofriendly synthesis of silver nanoparticles from commercially available plant powders and their antibacterial properties. Scientia Iranica 20: 1049-1054.

16. Kumar PV, Pammi SVN, Kollu P, Satyanarayana KVV, Shameem U (2014) Green synthesis and characterization of silver nanoparticles using Boerhaavia diffusa plant extract and their anti-bacterial activity. Industrial Crops and Products 52: 562-566.

17. Oh S, Minji J, Kim J, Lee J, Zhou H, et al. (2016) Synthesis of silver nanoparticles using analogous reducibility of phytochemicals. Current Applied Physics 16 738-747.

18. Gong P, Li H, He X, Wang K, Hu J, et al. (2007) Preparation and antibacteria activity of $\mathrm{Fe}_{3} \mathrm{O}_{4} \& \mathrm{Ag}$ nanoparticles. Nanotechnol 18: 604-611. 